\title{
Bridging Ecological Rehabilitation and Socio Cognitive Psychology
}

\author{
${\text { Carla } \text { Khater }^{1 *} \text {, Johnny Fenianos }}^{1,2}$, Denis Brouillet ${ }^{2}$ and Nicolas Arnaud ${ }^{3}$ \\ ${ }^{1}$ Center for Remote Sensing, National Council for Scientific Research Lebanon, Lebanon \\ ${ }^{2}$ Laboratoire Epsylon, University Paul Valéry, France \\ ${ }^{3}$ OSU OREME \& Géosciences Montpellier, Université de Montpellier/CNRS, France
}

Submission: February 04, 2019; Published: February 13, 2019

*Corresponding author: Carla Khater, Center for Remote Sensing- National Council for Scientific Research Lebanon, Bir Hassan- BP 11-8281 Riad El Solh, Beirut- Lebanon

\begin{abstract}
While ecological rehabilitation is improving rapidly, the transfer and implementation of its techniques are still sparse, and notably in environments where consistent interactions with human communities require the appropriation and adoption of new intervention methods. How can we overcome the existing resistance of decision-makers, and win acceptance on proposed innovative and technical solutions? This paper falls at the convergence of ecological rehabilitation and socio cognitive psychology. It builds on the learning provided by social and cognitive psychology and intends to reconcile the environmental priorities with the perceptions and expectations of human communities. It presents a parallel analysis of the methodological approaches adopted in both ecological rehabilitations when dealing with degraded ecosystems, and socio cognitive psychology when dealing with communities aiming to enable optimal ecosystem rehabilitation. The paper concludes on the importance of cross disciplinary approaches enabling to concile ecosystems needs with the expectations and specificities of target communities.
\end{abstract}

Keywords: Transdisciplinarity; Restoration ecology; Socio cognitive psychology; Cognitive sciences; Behavioral change; Perception modification

\section{Advocacy for a Radical Transdisciplinary Approach Mixing Ecology and Psychology}

If as confirmed in Roberts et al. [1], the future of our planet largely depends on our ability to mitigate and correct the effect of global change, which in turn requires the mastering of the "young discipline" that is ecological restoration, it is our duty to invest in the preservation and improvement of ecosystem services, ecological connectivity and biological cycles that rely on the functioning of corrupted ecosystems.

Knowledge of Mediterranean ecosystems and mastering of ecological engineering techniques have made substantial progress during the last decades. Unfortunately, the transfer of these techniques to the field and their implementation are still sparse, and notably in environments where consistent interactions with human communities require the appropriation and adoption of intervention methods.

A review of scientific articles [2-10], and technical books [11-14] on ecological rehabilitation brought to light the lack of effective ways to transfer methods and tools, from the scientific community to decision-makers and rehabilitation contributors (engineers, technicians and other stakeholders). The main obstacle to the implementation of ecological rehabilitation projects remains its social dimension [15-17] related to investment issues, access, land use conflicts, cognitive resistance to change, and interpersonal aspects $[17,18]$.

The Mediterranean basin, considered a hotspot for cultural and natural diversity, have evolved in tense and often unstable socio-political conditions, along with huge demographic increase, poorly-planned urbanization and a long history of coevolution of men and landscapes dating back to the Neolithic period. In this context, it becomes more pressing to take into consideration the diversity of human communities who have different visions and therefore different expectations and perceptions which leads to the necessity to adapt intervention methods and approaches in the proposal and implementation of ecological rehabilitation projects. Is it possible to bridge the expectations of some, the needs of others and benefits for all?

This paper presents a radically transdisciplinary approach through the coeval development of ecology - and in particular restoration ecology - and psychology - in terms of psycho social cognitive psychology - and suggests a mixed methodological approach combining both disciplines and bridging environmental priorities and human community's perceptions and expectation to reach effective adapted rehabilitation. 


\section{Ecology and Psychology at work}

Any environmental project involves several and possibly conflicting parts of an ecosystem and most notably physical, and biological components, the latter including human communities. This is especially the case in ecological rehabilitation projects incurring substantial changes in the living environment of people.

Ecological rehabilitation is the practice of restoring ecosystems as performed by practitioners at specific project sites, and socio cognitive psychology is based on social psychology ap- proaches and tools inspired from cognitive psychology aiming to induce increased acceptability, reduced resistance to change and to promote behavioral change with regards to a particular issue or project.

But in fact, both follow very similar lines of development, Figure 1 presents a parallel analysis of the methodological approaches adopted in both ecological rehabilitations when dealing with degraded ecosystems, and socio cognitive psychology when dealing with communities aiming to enable optimal ecosystem ecological rehabilitation.

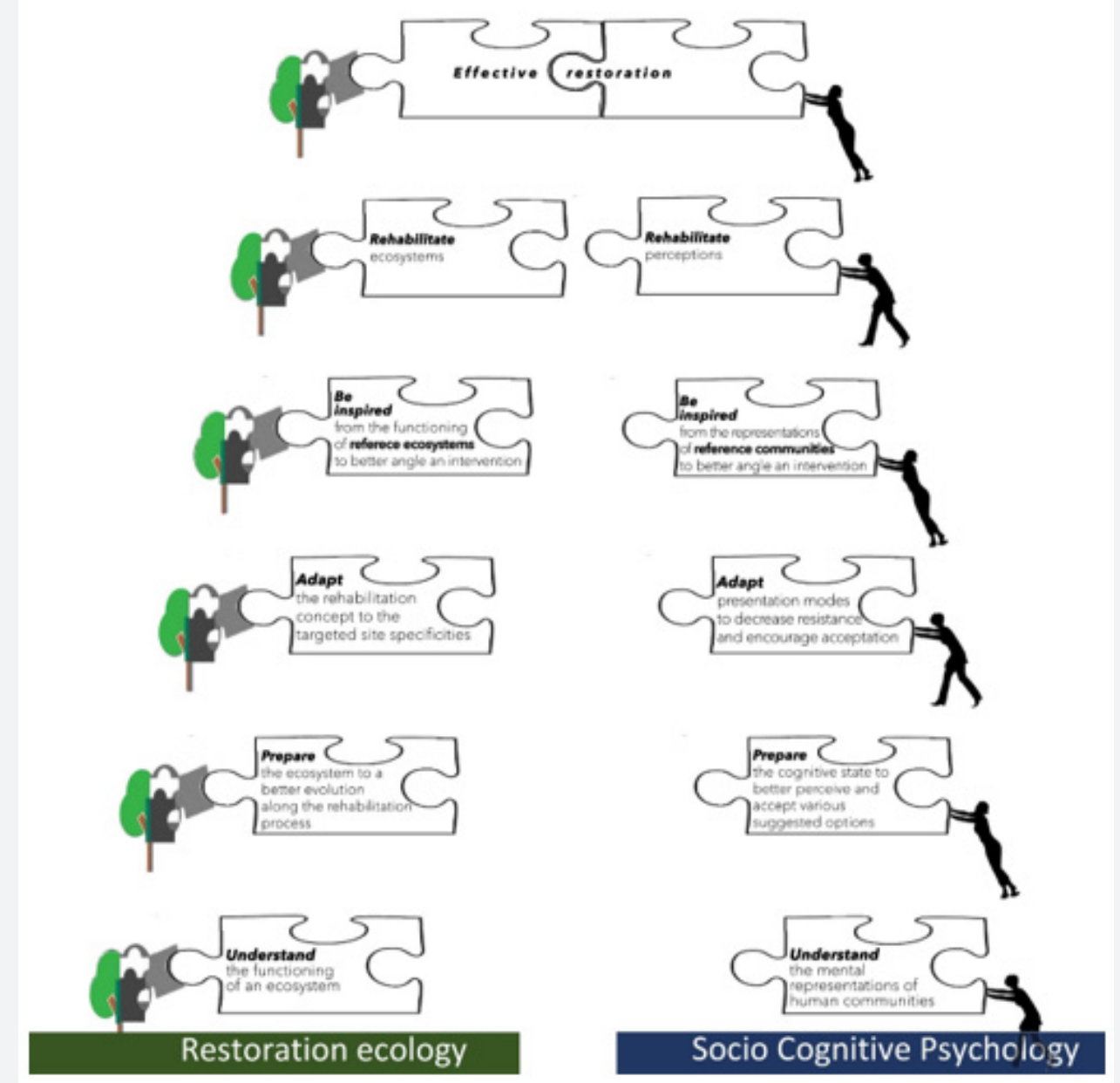

Figure 1: Thematic disciplinary analysis of ecological rehabilitation and socio cognitive psychology.

a) In ecological rehabilitation, every project starts by building a baseline understanding of the ecosystem structure and functions; It consists on a series of field work aiming to describe the habitats, assess the fauna and flora and define the requirements and threats on key species and habitats. It includes an assessment of the topography, geology and hydrology dynamics on the site. Similarly, in socio cognitive psychology, it is important to start by understanding the mental representation of target communities in terms of lateral perception and cognitive barriers. It is based on set of tools that will highlight the major obstacles in the mental state of the persons either cultural, emotional or beliefs.

b) The second strep in ecological psychology will concern preparing communities' state of mind to better perceive and accept the project. It is done through a set of techniques such as cognitive flexibility $[19,20]$ aiming to enable the state of mind of an individual or a group of individuals to accept another reality or break from preset schemas. Similarly, in ecological rehabilitation, the next step would concern 
preparing the ecosystem to the rehabilitation concept; it consists on a series of actions such as land forming, facilitating the access, orienting water runoff, limiting erosion on the site; it might also involve terracing or some minor input of exogenous environmentally friendly material (wood, stones....).

c) Adapting the rehabilitation concept is the core step of an ecological project as it enables to account for site specificities, rehabilitation objectives, obstacles and means to develop the "future to be" concept and design for the site. The second step in socio cognitive psychology will concern adapting communities' state of mind to better perceive and accept the project. It is done through a set of techniques such as cognitive flexibility $[19,20]$ aiming to enable the state of mind of an individual or a group of individuals to accept another reality or break from preset schemas. This step should be combined with awareness raising sessions and/or training on site knowing that this method is time demanding [21].

d) Any ecological rehabilitation concept should be inspired from the functioning of a reference ecosystem. The reference ecosystem [22] being a state of reference to the degraded ecosystem and towards which the rehabilitation should lead or at least tend to. Similarly, no consultation or collaborative development can involve the whole population affected or concerned by a project. The reference community is that group of people selected for a project's purpose and representing the community in terms of social groups, age and gender distribution. The perception analysis is performed on this reference group and results are afterwards applied and extended to the whole community.

e) The ultimate aim on a rehabilitation project is to rehabilitate the ecosystems and reach a stable stage enabling it to continue its natural dynamics with as less as possible human interventions. In parallel, in socio cognitive psychology, the purpose is to rehabilitate perceptions in a way that the community accepts and better appropriates and includes the site as part of their living environment (Umwelt: each living species has its own universe: it modifies its environment just as much as it is modified by it).

Even if these disciplines have evolved on separate paths, a transversal look at both of them sheds the light on their converging objectives and methodologies. This strongly suggests that co-development of both methodologies might be important, not to say key, to the success of the rehabilitation of ecosystems, since this convergence eventually bridges the needs of some and the expectation of others, i.e. the needs of ecosystems and the expectations of human communities [23-26].

In both cases, the objective is to understand, prepare and adapt, based on a referential situation, in order to improve the management/rehabilitation abilities of natural sites.

\section{Conclusion}

In the complex interactions of human communities with natural ecosystems, and in the global trend promoting multi and cross disciplinary approaches, it becomes of an utmost urge that methodologies and preparatory work account equally for ecosystems, biological and habitat diversity as the same level as cultural and social diversity. Socio cognitive psychology offers tools that enable to better understand mental settings and perceptions, thus guiding the way to better adapt ecological interventions. The convergence between ecology and psychology might be one of the ways to reach optimum effective ecological rehabilitation.

\section{Acknowledgements}

This research is part of two projects "TREET" and "RESTORE" funded by Grant Research Program- CNRS, and CEDRE Program. This is a LIA O-LiFE contribution number SA 47-2019.

The authors would like to acknowledge and thank Dr. Jalal Tabel for editing the final version of this manuscript.

\section{Conflict of Interest}

The authors declare that the research was conducted in the absence of any commercial or financial relationships that could be construed as a potential conflict of interest.

\section{References}

1. Roberts L, Stone R, Sugden A (2009) The rise of restoration ecology. Science 325(5940): 555.

2. Khater C, Martin A, Maillet J (2003) Spontaneous vegetation dynamics and restoration prospects for limestone quarries in Lebanon. Applied vegetation science 6(2): 199-204.

3. Van Diggelen R, Marrs RH (2003) Restoring plant CommunitiesIntroduction. Applied Vegetation Science 6(2): 106-110.

4. Khater C, Martin A (2007) Application of restoration ecology principles to the practice of limestone quarry rehabilitation in Lebanon. Lebanese Science Journal 8(1): 19-28.

5. Walker LR, del Moral R (2009) Transition dynamics in succession: implications for rates, trajectories and restoration. New models for ecosystem dynamics and restoration, pp. 33-49.

6. Darwish T, Khater C, Jomaa I, Stehouwer R, Shaban A, et al. (2011) Environmental impact of quarries on natural resources in Lebanon. Land Degradation \& Development 22(3): 345-358.

7. Phillips J (2012) The level and nature of sustainability for clusters of abandoned limestone quarries in the southern Palestinian West Bank. Applied Geography 32(2): 376-392.

8. Oldfield EE, Warren RJ, Felson AJ, Bradford MA (2013) Challenges and future directions in urban afforestation. Journal of Applied Ecology 50(5): 1169-1177.

9. Prach K, Tolvanen A (2016) How can we restore biodiversity and ecosystem services in mining and industrial sites? Environmental Science and Pollution Research 23(14): 13587-13590.

10. Bulot A, Potard K, Bureau F, Bérard A, Dutoit T (2017) Ecological restoration by soil transfer : impacts on restored soil profiles and topsoil functions. Restoration Ecology 25(3): 354-366. 
11. Correia O, Clemente AS, Correia AI, Máguas C, Carolino M, et al. (1970) Quarry rehabilitation: a case study. WIT Transactions on Ecology and the Environment 46.

12. Williamson GM, Shaffer DR, Schulz R (1998) Activity restriction and prior relationship history as contributors to mental health outcomes among middle-aged and older spousal caregivers. Health Psychology 17(2): 152-162.

13. WBCSD (2011) Cement Sustainability Initiative (CSI). Business solutions for a sustainable world. ISBN: 978-3-940388-82-7.

14. Pamba S (2014) The Potential Use of Aquatic Ecosystem for Enhancement of Rehabilitation of Mining Site: A Case of Wazo Hill, Tanzania. Quarry Life.

15. Jacobson N, Butterill D, Goering P (2004) Organizational factors that influence university-based researchers' engagement in knowledge transfer activities. Science Communication 25(3): 246-259.

16. Weerts DJ, Sandmann LR (2008) Building a two-way street: Challenges and opportunities for community engagement at research universities. The Review of Higher Education 32(1): 73-106.

17. Khater C (2015) L'écologie appliquée : une responsabilité scientifique au carrefour de l'interdisciplinarité. HDR. Université Aix-Marseille.

18. Fenianos J, Khater C, Viglione J, Brouillet D (2017) Bridging nature and human priorities in ecological rehabilitation projects - a show case from Mediterranean environment - Qattine, Lebanon. Plant Sociology 54 Suppl 1: 103-110.
19. Spiro RJ (1988) Cognitive Flexibility Theory: Advanced Knowledge Acquisition in Ill-Structured Domains. Technical Report No. 441.

20. Cañas J, Quesada J, Antolí A, Fajardo I (2003) Cognitive flexibility and adaptability to environmental changes in dynamic complex problemsolving tasks. Ergonomics 46(5): 482-501.

21. Fenianos J, Khater C, Brouillet D (2018) When Psychology Meets Ecology: Cognitive Flexibility for Quarry Rehabilitation'. World Academy of Science, Engineering and Technology, International Science Index 137, International Journal of Medical, Health, Biomedical, Bioengineering and Pharmaceutical Engineering 12(5): 217 - 223.

22.SER (2002) Society for Ecological Restoration Science and Policy Working Group. The SER Primer on Ecological Restoration.

23. Thompson JD (2005) Plant evolution in the Mediterranean. Oxford University Press, Oxford, USA.

24. Fenianos Johnnym, Khater Carla, Brouillet Denis. In revision. A simple tool to account for the spatial specificities of stakeholders in ecological rehabilitation projects: A Flash test. Ecologia mediterranea.

25. Jordan WR (1987) Restoration ecology: ecological restoration as a technique for basic research. Restoration ecology: a synthetic approach to ecological research.

26. Le Floc'h E, Aronson J (1995) Ecologie de la restauration, définition de quelques concepts de base." Natures Sciences Societes Hors série: 29-35.

\section{Your next submission with Juniper Publishers} will reach you the below assets

- Quality Editorial service

- Swift Peer Review

- Reprints availability

- E-prints Service

- Manuscript Podcast for convenient understanding

- Global attainment for your research

- Manuscript accessibility in different formats

( Pdf, E-pub, Full Text, Audio)

- Unceasing customer service

Track the below URL for one-step submission https://juniperpublishers.com/online-submission.php 